\author{
Iryna Babets \\ Doctor of Economic Sciences, Professor, \\ Department of International Economic Relations \\ Central Ukrainian National Technical University, Kropyvnytskyi, Ukraine \\ E-mail:irina.babets@ukr.net \\ ORCID: https://orcid.org/0000-0003-0635-9375 \\ Mariya Fleychuk \\ Doctor of Economic Sciences, Professor, Department of Marketing \\ Lviv National University of Veterinary Medicine and Biotechnologies named after S.Z. Gzhytskyi, Lviv, Ukraine \\ E-mail: fleychukm@gmail.com \\ ORCID: https://orcid.org/0000-0002-0417-9066
}

\title{
Marketing tools for international tourism flows balancing: experience of Ukraine and Poland
}

\begin{abstract}
The article provides a comparative analysis of trends in domestic and foreign tourism in Ukraine and Poland during the COVID-19 pandemic. The main directions and tools of marketing policy of balancing tourist flows for socio-economic development of the researched countries are analyzed. The main subject of the research is marketing tools for balancing international tourist flows in the investigated countries, taking into account the experience of other countries in which the field of tourism is developed. The research methodology provides for the analysis of the dynamics of tourist flows in Poland and Ukraine, the use of methods and tools of fuzzy logic using Mathlab software and the use of a matrix method of analysis to study the development of tourism at the regional level. The study used data from the World Bank, the International Monetary Fund in post-socialist countries, as well as the results of the Global Market Research-2020 and data from statistical agencies of Ukraine and Poland. It is emphasized that formation of an effective marketing policy to balance the flow of international tourism at the local level should be with the participation of the private sector and local governments. The purpose of the article: outline marketing tools for balancing international tourism flows in Ukraine and Poland, especially during the COVID-19 pandemic. Conclusions. In summary, the study identified such generalized tools of modern marketing that are most relevant in the development of policies to balance tourist flows in Ukraine and Poland, as well as in other countries, especially in the pandemic Covid-19: creating content for electronic networks (content), social media marketing (SMM), landing page or standard website, search engine optimization (SEO), media advertising, teaser advertising, consumer product support, e-mails (emails), viral marketing, strategic partnership, CPA-marketing, creation of a marketing channel, application of a comprehensive strategy of smart-tourism.
\end{abstract}

\section{Keywords}

Marketing tools, international tourism flows balancing, experience of Ukraine and Poland, COVID-19, crises in tourism branch

JEL: M31, F22, L83, F15, F01, E61

DOI: https://doi.org/10.30525/2500-946X/2021-2-5

\section{Introduction}

The pandemic caused by the COVID-19 virus has added new challenges and exacerbated threats to the development of tourism services in Ukraine. Strict restrictions in international tourism have significantly reduced the profits of domestic travel companies focused on serving outbound tourists. At the same time, the development of domestic tourist infrastructure, both in terms of the number of facilities and the quality of services, lags far behind the needs of domestic and foreign tourists. In this regard, the main task is to find effective ways to develop the tourism industry in a crisis and reduce the impact of threats, especially internal, which can lead to the destruction of infrastructure and human resources of tourism potential.

The main objectives of the study: investigate trends in tourist flows in Ukraine and Poland during the Covid-19 pandemic; to determine the main directions of marketing policy of balancing international tourist flows in the studied countries; summarize the positive experience of using marketing tools to balance international tourist flows.

Problems of marketing policy research both at the general theoretical level and within certain highly specialized aspects in the applied sense were considered in the works of many domestic and foreign scientists. In particular, A. Vynogradska, A. Tereshchenko, V. Dyachenko, R. Muszkieta, M. Napierała, M. Barszczak, W. Zukow, A. Stasiak, A. Rochminska, C. E. Czernicki, P. Kukołowicz, M. Miniszewski, V. Kuznetsov, F. Kotler, L. Melnyk, V. Gerasymenko, T. Tkachenko, N. Nechayuk, L. Vorotina and others.

Some elements of modern Internet marketing asects are studied in the works of R. Ambler, Y. Bilyavska, J. Verkman, A. Deyan, P. Doyle, J. Evans, S. Ilyashenko, J.-N. Kapferer, K. Keller, S. Kumber, J.-J. Lamben, E. Mayovets, P. Miniard, T. Nilsson, M. Porter, E. Rice, B. Semak, C. Sandig, D. Trout, G. Charmeson, and others. 


\section{Expirience of Ukraine}

Ukraine is a tourist attractive country and has all the opportunities for the development of tourism as a priority sector of the economy. The Tourism and Resorts Development Strategy until 2026 identifies tourism as one of the main sectors of economic development, as it is associated with more than 50 industries, its development contributes to employment, diversification of the national economy, preservation and development of cultural potential, preservation of ecologically safe natural environment, and also raises a level of innovation of national economy, promotes harmonization of relations between the different countries and the people (Rozporiadzhennia, 2017). However, the introduction of quarantine restrictive measures to prevent the spread of the COVID-19 pandemic has significantly reduced the efficiency of the tourism services use in our country and negatively affected the volume of inbound tourism, which was still much lower than outbound flows.

Given the deepening economic crisis in Ukraine caused by the sanitary and epidemiological situation in the world and the in the country, and given the significant reduction in tourist flows in 2020 due to quarantine restrictions, the obvious and urgent way out of the crisis is balancing incoming and outgoing tourism flows. However, for domestic tour operators, encouraging foreign tourists is a challenge that requires a combination of efforts not only from different tourism actors, but also from local authorities. The main task is to comprehensively study, organize and develop all available in Ukraine places and resources for tourism, which should become the centers of the domestic tourism industry and promote the further development of domestic and outbound tourism. This task is complicated by the persistent advantage of foreign recreation over domestic tourism in the preferences of domestic consumers of tourism products.

In 2011-2019, the number of travelers within Ukraine decreased: from 497.5 to 449.6 thousand persons (by $4.5 \%$ ). At the same time, the number of tourists who went on vacation outside of Ukraine increased from 1.3 to 2.3 million persons. During 2014-2019, the share of domestic tourists in the total number of tourists in Ukraine decreased more than twice, which indicates the reorientation of these tourists to foreign holidays - the number of outbound tourists increased from 2085 thousand people in 2014 to 4786.6 thousand persons in 2019 (Table 1).
Dynamics of tourist flows in Ukraine in 2014-2019, thousand people in 2011-2019, the number of travelers within Ukraine decreased: from 497.5 to 449.6 thousand people (by $4.5 \%$ ). At the same time, the number of tourists who went on vacation outside of Ukraine increased from 1.3 to 2.3 million people. During 2014-2019, the share of domestic tourists in the total number of tourists in Ukraine decreased more than twice, which indicates the reorientation of these tourists to foreign holidays the number of outbound tourists increased from 2085 thousand people in 2014 to 4786.6 thousand people in 2019 (Table 1).

In general, in 2019 , only $1.6 \%$ of tourists from the total tourist flow entered Ukraine. The dynamics of the ratio of the outbound tourists number to the number of domestic had a steady growing trend, reaching in 2019 the maximum value for the study period. This indicates a decrease in the competitiveness of tourist facilities in Ukraine and the lack of interest or inability of domestic tourism market operators in the development of domestic tourist routes. This is confirmed by changes in the structure of tourists served by travel destinations for the period 2011-2019 - the number of travelers within Ukraine decreased from 497.5 to 449.6 thousand people (by $4.5 \%$ ) while increasing the outbound tourist flow from 1.3 million to 2.3 million.

The negative processes taking place in the tourism industry are also reflected in the dynamics of the main indicators of foreign trade in travel-related services (Figure 1). The number of Ukrainian citizens who went abroad significantly exceeds the number of foreigners who visited Ukraine, which causes a negative balance of tourist flows during 2010-2020. In the structure of exports of Ukrainian services, the share of travel-related services is relatively stable, not exceeding $3 \%$ over the last ten years and decreased from $2.8 \%$ in 2012 to $2.3 \%$ in 2020, indicating stagnation in the tourism sector and inefficient use of tourism potential.

The structure of tourist services in Ukraine is unbalanced, as the total number of tourists is dominated by people whose purpose of travel was leisure and recreation. The share of this type of services in the total volume of tourist services increased from $87.8 \%$ in 2011 to $93.3 \%$ in 2019 (Turystychna, 2020).

At the same time, the share of tourists who received services for treatment, sports and specialized tourism in 2019 was $1.05 \%, 0.07 \%$ and $0.4 \%$ of the total number of

TABLE 1 Dynamics of tourist flows in Ukraine in 2014-2019, thousand people

\begin{tabular}{|c|c|c|c|c|c|c|}
\hline Indicator & 2014 & 2015 & 2016 & 2017 & 2018 & 2019 \\
\hline $\begin{array}{l}\text { Number of tourists served by tour } \\
\text { operators and travel agents, total }\end{array}$ & 2425 & 2019 & 2550 & 2806 & 4557 & 5319,9 \\
\hline \multicolumn{7}{|l|}{ between them: } \\
\hline incoming (foreign) tourists & 17 & 15 & 35 & 39 & 76 & 83,7 \\
\hline share in total, $\%$ & 0,7 & 0,7 & 1,4 & 1,4 & 1,7 & 1,6 \\
\hline outbound tourists & 2085 & 1647 & 2061 & 2290 & 4023 & 4786,6 \\
\hline share in total, $\%$ & 86,0 & 81,6 & 80,8 & 81,6 & 88,3 & 89,9 \\
\hline domestic tourists & 323 & 357 & 454 & 477 & 457 & 449,6 \\
\hline share in total, \% & 13,3 & 17,7 & 17,8 & 17,0 & 10,0 & 8,5 \\
\hline $\begin{array}{l}\text { The ratio of the number of outbound } \\
\text { tourists to domestic }\end{array}$ & 6,4 & 4,6 & 4,5 & 4,8 & 8,8 & 10,6 \\
\hline
\end{tabular}

Source: calculated for (Turystychna, 2020) 


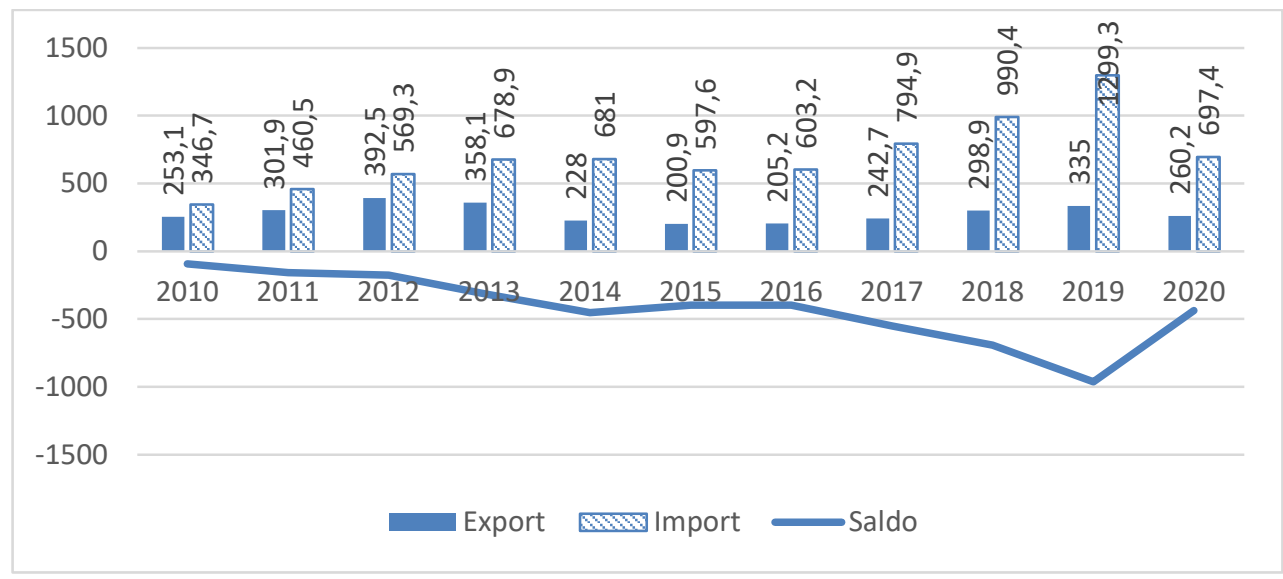

FIGURE 1 Dynamics of indicators of foreign trade of Ukraine in services related to travel, million dollars USA

Source: built using (Dynamika zovnishnoi, 2020)

tourists served by tour operators (Rozpodil turystiv, 2019). The value of this indicator decreased compared to 2011 for the number of tourists whose purpose of travel was treatment (8.8\%) and sports $(2.3 \%)$, and increased among consumers of specialized services $(0.17 \%)$.

Such a situation is not typical for developed countries, as well as countries with a higher level of tourism development. According to scientists, "such a structure of consumption of tourist services does not contribute to the balanced progress of the domestic tourist complex, especially given the high potential of medical, green, sports and other types of tourism" (Vasyltsiv, 2019).

At the same time, in the structure of inbound tourism, the share of tourists who came to Ukraine in 2019 for leisure and recreation was $69.8 \%$, for treatment $2.8 \%$, sports tourism $-0.23 \%$ and specialized tourism 20.1\% (Rozpodil turystiv, 2019), which indicates the attractiveness for foreign tourists of treatment, business and SPA tourism services provided by domestic tourism market participants.

In fact, the development of these types of tourist services, with special emphasis on post-cognitive rehabilitation, we consider one of the basic directions of the tourism sector out of crisis in a pandemic. As a result of quarantine restrictions, the number of foreigners resting in sanatoriums has decreased, and domestic tourists have limited financial opportunities for health recreation due to the economic crisis. The problem of intensifying the activities of health and preventive treatment facilities can be solved through the introduction of state co-financing of rehabilitation programs for people who have become ill with coronavirus.

We consider the formation of tourist centers near places of outstanding historical events, architectural monuments or unique natural landscapes to be no less important in the development of tourism in Ukraine. In this regard, the relevant measures will identify the following: restoration, development or creation of relevant tourist facilities; conducting a large-scale advertising campaign to disseminate information about attractive tourist destinations; implementation of state programs on patriotic education of youth in order to promote historical tourism; providing financial support by local authorities for the development of tourist sites related to historical events or folk traditions.

\section{Expirience of Poland}

In the context of the global crisis and the COVID-19 virus pandemic, countries where tourism is focused on domestic tourists have better conditions for preserving the national tourism industry. The intensification of competition in the field of tourism encourages industry to reconsider approaches to ensuring the quality and content of tourism services, to use new effective forms and ways to encourage tourists to consume tourism services in the domestic market. In view of the above, in order to solve the problem of balancing inbound and outbound tourist flows in Ukraine, it is advisable to analyze the experience of Poland.

The service sector accounts for about $60 \%$ of the overall structure of the Polish economy. The tourism industry is developing rapidly, and the share of tourism in the country's GDP is 4.5\% (Turystyka, 2019). However, during 2007-2010, the number of foreign tourists who came to Poland on holiday tended to decrease. The biggest crisis was observed in 2008, when the number of tourists decreased to 12.96 million people or $13.5 \%$ compared to 2007 .

Since 2012, the number of tourist arrivals in the country, although not rapidly, is constantly growing (Figure 2). During 2019, according to the Ministry of Development of Poland, almost 88.52 million people came to the country, which is $3.0 \%$ more than in the corresponding period of the previous year. The number of tourists arrived was approximately 21.2 million people $(7.8 \%$ more than in 2018) (Więcej turystów, 2019). Residents of neighboring countries came to Poland, which in 2019 accounted for $60.0 \%$ of tourists and $97.1 \%$ of one-day visitors.

One-day visitors came to Poland mainly for shopping (54.4 million persons or almost $81 \%$ ), for leisure and entertainment (3.9 million persons or almost $6 \%$ ) and for business purposes (2.3 million persons or more than $3 \%$ ). The number of tourists for the main purposes of arrival in Poland differs depending on the country of origin (Table 2).

Thus, tourists from Germany came to Poland mainly to visit relatives and acquaintances $(54.7 \%$ of all visitors from this country) and for tourist purposes (28.1\%). A similar structure of the main purposes of arrivals in Poland is typical for tourists from the EU-14. The structure of the destinations of tourists arriving from Belarus, RF and 


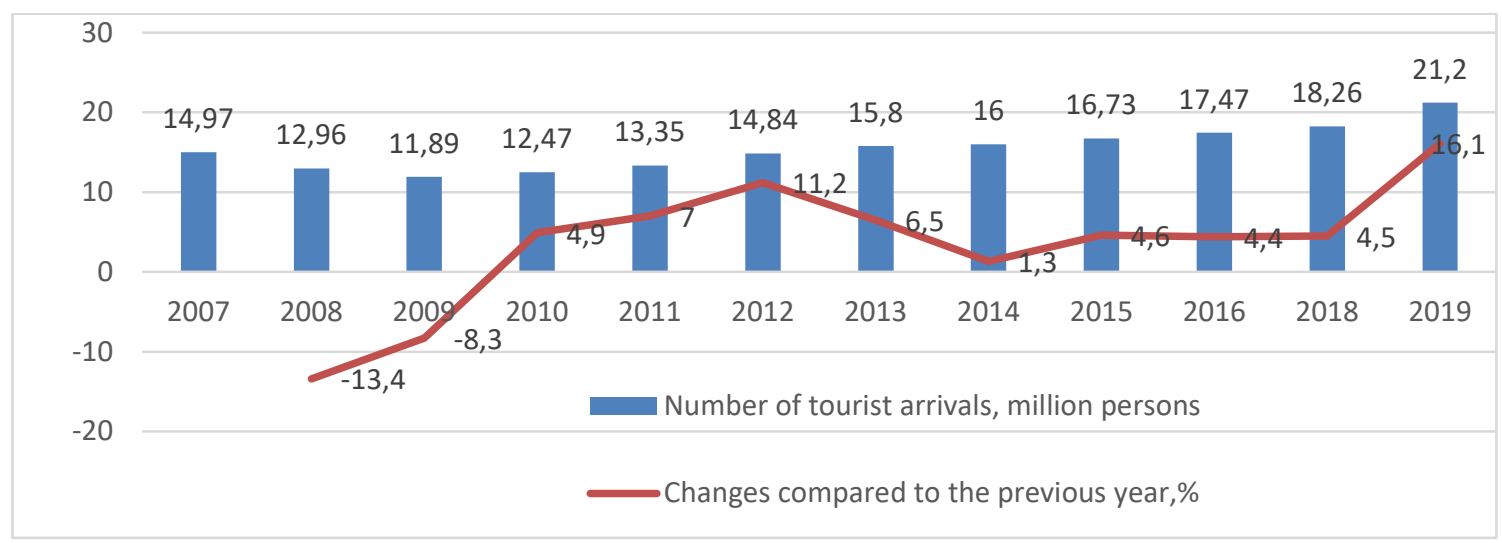

FIGURE 2 Dynamics of the number of tourist arrivals in Poland in 2007-2019 Source: calculated and based on data (Mirovoj atlas, 2019)

Ukraine is dominated by shopping (27.9\%) and transit on business trips (17.3\%).

According to the Department of Tourism of the Ministry of Development of Poland, in 2019 the share of arrivals in Poland for tourism purposes increased (+1.3 percentage points), while the share of arrivals for business purposes (-1.3 percentage points) and visitors of relatives and friends decreased (-1.2 percentage points) (Charakterystyka, 2019). Revenues from international tourism in Poland increased from 9576 million USD in 2010 to 14042 million USD in 2018 (by 46.6\%), and their share in the overall EU figure in 2018 was 2.5\% (International Tourism, 2020). Expenditures of foreigners arriving in Poland (including expenses before the trip in their country and in Poland) in 2019 amounted to 61.0 billion PLN, which is $4.5 \%$ more than in 2018 , of which tourists spent 37, PLN 1 billion $(7.3 \%$ more than in 2018), and one-day visitors - PLN 23.9 billion (0.4\% more than in 2018).

The average cost of tourists in Poland in 2019 amounted to 484 USD per capita, which was about $1.4 \%$ less than in 2018 , and 64 USD per day of stay $-7.2 \%$ less than in the previous year. As can be seen from the figure, the average costs by country vary considerably; these costs ranged from
\$233 (Czech Republic) to 1478 USD (Australia, Japan, Canada, South Korea) (Charakterystyka, 2019).

Compared to 2018, the growth of average costs per person was recorded mainly among tourists from Ukraine (by $1.2 \%$ ). Among other major markets that generate tourist traffic to Poland, there was a decrease in costs per capita, expressed in USD. Such trends characterize the average cost of tourists per day of stay. In the period from January to December 2019, they ranged from approximately $\$ 46$ (UK) up to \$ 98 (Lithuania) and \$94. (RF) (Charakterystyka, 2019).

In 2019, the largest expenditures were made by persons who visited Poland for health purposes (approximately USD 705 per person), for participation in conferences and congresses (USD 540) and for tourism purposes (USD 514). It should be emphasized that the average costs of tourists traveling for family purposes remain relatively high (Charakterystyka, 2019).

The increase in the number of tourist arrivals, and hence the income from international tourism at the present stage, is largely due to the diversification of the tourist product. Today, Poland can offer foreign guests a wide range of tourist attractions. Summer vacations are traditionally spent in Warmia and Mazury, among forests

TABLE 2 The structure of foreign arrivals in Poland depending on the purpose of the trip in 2019

\begin{tabular}{|c|c|c|c|c|}
\hline \multirow{2}{*}{ Main purpose of arrival (\%) } & \multirow{2}{*}{ In general } & \multicolumn{3}{|c|}{ For individual countries } \\
\hline & & Germany & EU - 14 & Belarus, RF, Ukraine \\
\hline Business trip, incl. & 22,5 & 10 & 20,2 & 30 \\
\hline business issues & 13,4 & 8,2 & 16,1 & 10,9 \\
\hline participation in the conference & 1,4 & 0,9 & 2,8 & 0,7 \\
\hline participation in exhibitions, fairs & 0,5 & 0,4 & 0,8 & 0,4 \\
\hline transit & 6,7 & 0,4 & 0,2 & 17,3 \\
\hline another purpose of the business trip & 0,5 & 0,2 & 0,3 & 0,7 \\
\hline Tourist vacation & 28,8 & 28,1 & 35,9 & 14,9 \\
\hline Visiting relatives and acquaintances & 34,6 & 54,7 & 36,9 & 12,5 \\
\hline Transit for private use & 3,0 & 1,3 & 0,5 & 11,1 \\
\hline Shopping & 6,4 & 1,4 & 0,4 & 27,9 \\
\hline Healing and treatment & 1,4 & 2,1 & 2,0 & 0,5 \\
\hline Religious & 1,0 & 0,8 & 1,3 & 0,5 \\
\hline Other goals & 2,3 & 1,6 & 2,8 & 2,6 \\
\hline
\end{tabular}

Source: (Charakterystyka, 2019) 
and giant lakes, in winter they go skiing in the mountain resorts of the Tatras and Bieszczady. In addition, they rest both in summer and in winter in the Sudetenland, in the warm season on the Baltic coast (Czernicki, 2020). And all this is much cheaper than in other EU member states. On the one hand, there is a growing interest in Poland among foreigners, as evidenced by the steady growth of inbound tourist flow. On the other hand, the streamlining of the domestic market of tourist services has affected the growth of domestic tourism and a corresponding decrease in outbound tourism. That is, the trend of excess outbound over inbound in the structure of international tourism, which was dominant throughout almost the entire period of formation, is gradually being replaced by the reverse, which may indicate the stabilization of the national market of tourist services in Poland.

Domestic tourism is developing intensively in Poland. "Good, because Polish" is an advertising slogan for many Polish food products that can be safely used to promote tourism among Poles themselves, which, however, is already being successfully implemented. In 2006 alone, 9,800,000 Polish citizens became tourists in their country. In 2012, their number increased to 17.7 million people, and in 2017 - to 25.2 million people.

For two years, the Polish Ministry of Development, which takes care of tourism in the country, has been organizing a nationwide action "Poland: more nearby - weekends for half price". We are talking about the use of such a formula for discounts on holidays during the weekend, which is already in force in various Polish cities and regions, as well as its transfer to the national level. The project is aimed at administrators of the tourism industry and tourist attractions, as well as individual tourists, who from March 1 to April 2 can take advantage of a special discount of $50 \%$. In 2017, about 400 organizations offering tourist services took part in this action, and 60,000 tourists took advantage of the offer. The ambitious goal of the project "Poland: more nearby - weekends for half price" is to reach 100 thousand domestic consumers to revive domestic tourism in the country and increase the impact of this industry on the dynamics of economic development (Trehub, 2020).

Travel expenses of Polish residents in 2019 amounted to PLN 79.5 billion (an increase of $9.7 \%$ compared to the previous year), of which PLN 30.9 billion fell on domestic overnight stays (an increase of $11.5 \%$ ), for trips abroad with overnight stays - PLN 34.3 billion (increase by $9.2 \%$ ), and for one-day trips abroad - PLN 14.4 billion (increase by $7.0 \%)$. Expenditures on domestic trips with overnight stays accounted for $38.8 \%$ of total expenditures (by 0.6 percentage points), and on trips abroad with overnight stays $-43.2 \%$ (0.2 percentage points less). Expenditures on one-day trips abroad amounted to $18.1 \%$ (down 0.4 percentage points).

In 2019, the average cost per capita for a domestic trip lasting from 2 to 4 days was PLN 352 (an increase of 7.6\%), and for a trip lasting 5 days or longer - PLN 1,012 (an increase of $4.6 \%$ ), and for foreign, respectively 1708 zlotys (decrease by 2.3\%) and 2737 zlotys (increase by 3.5\%). One person spent an average of PLN 388 per trip abroad without an overnight stay (an increase of 3.7\%). The cost structure in 2019 varied depending on the type of trip and its duration. In the case of short-term domestic travel, in addition to a relatively large share of food (30.3\%) and transport (26.3\%), a significant share of living expenses (24.4\%) and the purchase of goods (13.7\%). Compared to 2018 , in the structure of expenditures incurred during domestic short-term travel, the share of expenditures on transport (by 1.0 percentage points) and accommodation (by 0.7 percentage points) increased and the share of expenditures on purchases decreased (by 1.2 percentage points) percentage point).

During domestic trips lasting 5 days and longer, residents of Poland spent the most on accommodation $(37.6 \%$ of total expenditures), food (33.7\%) and transport (14.9\%). Compared to 2018 , living expenses increased the most in the structure of expenditures (by 1.1 percentage points). In the case of other categories, the changes were insignificant (Turystyka, 2019).

Strategic planning for the development of tourism services in Poland is carried out at the national level, as well as at the level of regions (voyevodships) and local authorities (gminnes). Multilevel strategy is based on initiative and cross-planning of tourism development as an element of development policy, coordinated by the Ministry of Sport and Tourism. The main tasks of strategic management are to reduce the fragmentation of the tourism market by creating an integrated approach to supporting the tourism economy as a source of activation around tourism products or services, both in urban and rural areas. At the same time, priority is given to instruments and decisions of tourism policy that promote employment growth and cooperation between economic entities and their environment within the network model of the economy, exchange of resources and strengthening regional growth potential.

The implementation of these areas is ensured by state programs in the field of tourism in Poland. The basic strategic document is "Poland's Marketing Strategy in the Tourism Sector for 2012-2020". The main goal of the strategy is to identify areas and forms of activity in the field of tourism, the most important for the promotion of Poland in the international tourism market. As a result of the strategic directions implementation, it is expected to improve the international position of Poland as an attractive and hospitable country for tourists, which has competitive tourism products of high quality.

The strategy is the main active tool of the Polish Tourism Organization and the tourism industry, necessary for the implementation of a consistent and long-term promotional policy of Poland in the tourism sector until 2020. According to the adopted "Polish Marketing Strategy in the Tourism Sector for 2012-2020", the activities of the Polish Tourism Organization are in the following areas: 1) strengthening the role of online communications, in particular in the field of tourism; 2) improving local and regional branding; 3) vertical and horizontal integration for the creation of tourism clusters, consortia, etc.; 4) intensification of public and private partnerships to increase the competitiveness of tourism in Poland; 5) strengthening the partnership in the joint financing of advertising activities, deepening marketing planning, etc. (Marketingowa strategia, 2020).

In accordance with the main directions of the considered strategic document, each region (voivodship) develops and implements a regional strategy for the development of the tourism sector. All regional strategies indicate as one of the priority areas of activity for the development and promotion of modern tourism (creation of tourism products that are attractive and competitive in the international market).

In 13 regions (Table 3 ) the leading tourist product is considered to be various forms of urban and cultural tourism (for example, sightseeing in cities, archeological, historical, military, industrial / technological monuments), as well 
TABLE 3 The main tourism products identified in the regional tourism strategies of Poland in 2012-2020

\begin{tabular}{|c|c|c|c|c|c|c|c|c|c|c|c|c|}
\hline \multirow[b]{2}{*}{ Voivodeship } & \multicolumn{12}{|c|}{ Type of tourism } \\
\hline & $\begin{array}{l}\text { है } \\
\text { है } \\
\text { है } \\
\text { है }\end{array}$ & "ृ & हु & : تृ & 흠 & 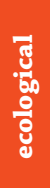 & 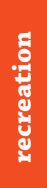 & $\begin{array}{l}0 \\
0 \\
0\end{array}$ & 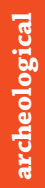 & 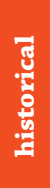 & 를 & 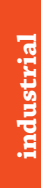 \\
\hline Lower Silesia & + & + & + & + & & + & + & & & & & \\
\hline Kuyavian-Pomeranian & & + & & + & & & + & & & & & \\
\hline Lubuskie & & + & & + & & + & & & & + & + & \\
\hline Lodz & & + & & + & & & + & & + & + & & + \\
\hline Lesser Poland & + & + & + & + & + & & + & + & & & & \\
\hline Opole & + & + & + & + & + & + & + & + & + & + & & + \\
\hline Subcarpathian & & + & + & + & & & & & + & & + & + \\
\hline Podlasie & + & + & + & + & + & & & + & & + & + & + \\
\hline Pomeranian & & + & + & + & & & & & & & & + \\
\hline Лbląskie & + & + & + & + & + & & & & & & + & + \\
\hline Hwiętokrzyskie & & + & + & + & & & + & & + & & & \\
\hline Warmian-Masurian & + & + & + & + & & & + & & & & & \\
\hline Wielkopolska & + & + & & & & & & + & + & + & & \\
\hline West Pomeranian & & & & + & & & + & & & & & \\
\hline Total & 7 & 13 & 9 & 13 & 4 & 3 & 8 & 4 & 5 & 5 & 4 & 6 \\
\hline
\end{tabular}

Source: compiled on the basis of strategic documents of Polish voivodships

as active and specialized tourism (for example, cycling, canoeing, sailing, hiking, skiing, etc.).

As part of the implementation of the information system of tourist services, various activities are carried out, the most common of which are the following: 1) certification of points for the provision of tourist information - IT points (seven voivodships); 2) creation of expansion of the regional tourist portal (six voivodships); 3) comprehensive marking of cities, roads and tourist attractions (six voivodships). However, for some regions a significant problem was the equipment of IT points with office equipment (not only modern office equipment, but also ordinary furniture).

Different priorities are set for the information direction implementation by the voivodship self-government bodies, which, of course, is the result of different state of tourist information in certain regions or current financial opportunities (for example, the need to wait for applications for relevant EU programs).

\section{Empirical research}

Using the tools of fuzzy logic, we have proved that increasing revenues from international tourists and increasing the level of spending on Internet marketing by travel agencies has a significant positive impact on GDP (Figure 3). The study used data from the World Bank (World bank, 2021), the International Monetary Fund (International Monetary Fund, 2021) in post-socialist countries, as well as the results of the global survey of tourism enterprises (Global Market Research, 2020). Thus, it is logical to countries and regions to intensify Internet marketing tools in order to improve socio-economic indicators in national economies as a whole. Given the above, it can be concluded that the formation of an effective marketing policy to balance the flow of international tourism at the local level should be with the participation of the private sector and local governments.

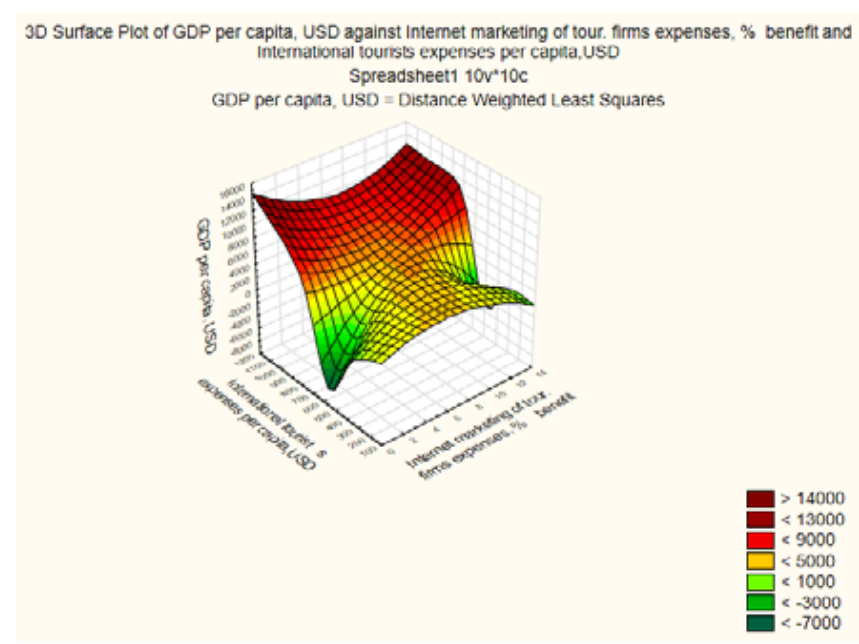

FIGURE 3 3D-modeling of the relationship between GDP per capita, the cost of foreign tourists per capita and the cost level of tourism enterprises for Internet marketing relative to profit (using fuzzy logic tools), 2020

It should be noted that the state coordinator of the tourist information system is the Polish Tourist Organization, instead, the creation and financing of municipal tourist information centers is initiated by local governments.

It should be noted that Ukraine has adopted a Strategy for the development of tourism and resorts until 2026 (approved by the Cabinet of Ministers of Ukraine dated March 16, 2017 № 168-r), which also provides for the joint efforts of public authorities and local governments, representatives of the tourism business, other sectors of the economy and civil society institutions to promote 
Ukraine in the world and form the image of Ukraine as a country attractive for tourism. This Strategy emphasizes the intensification of the role of local governments in the formation and implementation of a mechanism for regulating the development of the tourism industry in Ukraine. A new challenge for the development of territorial communities within the border regions of Ukraine was the reform of local self-government and decentralization of power, which allowed for active involvement in the development of cross-border tourism markets of local governments. This reform, firstly, formed the institutional framework for the participation of local communities in cross-border cooperation projects as full-fledged actors. Secondly, the responsibility placed on local governments for the development of their own territorial communities forces them to actively use the potential of cross-border cooperation in various fields, including tourism. In light of this, there is a need to find the influence of local governments at the basic level on the development of cross-border tourism markets in the new economic and institutional realities.

\section{Conclusions}

1. Ukraine is a tourist attractive country and has all the opportunities for the development of tourism as a priority sector of the economy. Given the deepening economic crisis in Ukraine caused by the sanitary and epidemiological situation in the world and the in the country, and given the significant reduction in tourist flows in 2020 due to quarantine restrictions, the obvious and urgent way out of the crisis is balancing incoming and outgoing tourism flows. However, for domestic tour operators, encouraging foreign tourists is a challenge that requires a combination of efforts not only from different tourism actors, but also from local authorities.

2. In the context of the global crisis and the COVID-19 virus pandemic, countries where tourism is focused on domestic tourists have better conditions for preserving the national tourism industry. The intensification of competition in the field of tourism encourages industry to reconsider approaches to ensuring the quality and content of tourism services, to use new effective forms and ways to encourage tourists to consume tourism services in the domestic market. In view of the above, in order to solve the problem of balancing inbound and outbound tourist flows in Ukraine, it is advisable to analyze the experience of Poland.

3. The study identified such generalized tools of modern marketing that are most relevant in the development of policies to balance tourist flows in Ukraine and Poland, as well as in other countries, especially in the pandemic Covid-19: creating content for electronic networks (content), social media marketing (SMM), landing page or standard website, search engine optimization (SEO), media advertising, teaser advertising, consumer product support, e-mails (emails), viral marketing, strategic partnership, CPA-marketing, creation of a marketing channel, application of a comprehensive strategy of smart-tourism.

4. It is logical to countries and regions to intensify Internet marketing tools in order to improve socio-economic indicators in national economies as a whole.

\section{References}

[1] Charakterystyka przyjazdów do Polski w 2019 roku [Characteristics of arrivals to Poland in 2019].

[2] Czernicki, E., Kukołowicz, P., \& Miniszewski, M. (2020). Branża turystyczna w Polsce. Obraz sprzed pandemii [The tourism industry in Poland. Pre-pandemic picture]. Warszawa, 26-27.

[3] Dynamika zovnishnoi torhivli posluhamy za vydamy [Dynamics of foreign trade in services by types]. E-source: http://www.ukrstat.gov.ua/operativ/operativ2008/zd/dseip/dseip2007_u.htm

[4] The structure of foreign trade in services by type in 2020 [The structure of foreign trade in services by type in 2020]. E-source: http://www.ukrstat.gov.ua/operativ/operativ2020/zd/ztp_kv/ztp_kv_u/arh_ztp_kv2020_u.html

[5] Global Market Research 2020. E-source: https://www.researchandmarkets.com/reports/5236454/global-marketresearch-2020

[6] International Monetary Fund. E-source: www.imf.org

[7] InternationalTourismHighlights2019Edition.E-source:https://www.e-unwto.org/doi/pdf/10.18111/9789284421152

[8] Marketingowa strategia Polski w sektorze turystyki na lata 2012-2020 [Marketing strategy of Poland in the tourism sector for 2012-2020].

[9] Mirovoj atlas dannyh: Polsha [World Data Atlas: Poland]. E-source: https://knoema.ru/atlas/Польша

[10] Rozpodil turystiv, obsluhovanykh turoperatoramy ta turahentamy, za metoiu poizdky ta vydamy turyzmu u 2019 rotsi. Derzhavna sluzhba statystyky Ukrainy. [Distribution of tourists served by tour operators and travel agents by purpose of travel and types of tourism in 2019. State Statistics Service of Ukraine]. E-source: http://www.ukrstat.gov.ua/operativ/menu/menu_u/tur_.htm

[11] Rozporiadzhennia KMU vid 16 bereznia 2017 r. № 168-r «Pro skhvalennia Stratehii rozvytku turyzmu ta kurortiv na period do 2026 roku» [Order of the Cabinet of Ministers of March 16, 2017 № 168-r "On approval of the Strategy for the development of tourism and resorts for the period up to 2026"]. E-source: https://zakon.rada.gov.ua/laws/ show/168-2017-\%D1\%80.

[12] Trehub, H. Yak Polshcha rozvyvaie turyzm [How Poland develops tourism]. E-source: https://tyzhden.ua/World/197523

[13] Turystychna diialnist v Ukraini. Statystychna informatsiia. Derzhavna sluzhba statystyky Ukrainy [Tourist activity in Ukraine. Statistical information. State Statistics Service of Ukraine] E-source: http://www.ukrstat.gov.ua/operativ/ menu/menu_u/tur_htm

[14] Turystyka w 2019 roku: Analizy statystyczne. Glowny Urząd Statystyczny [Statistical analyzes. Central Statistical Office]. Warszawa, 2020. 136 p.

[15] Turystyka w 2019 roku: Analizy statystyczne. Glowny Urząd Statystyczny. Warszawa, 2020. 136 p.

[16] Vasyltsiv, T. H., Lupak, R. L., Rudkovskyi, O. V., \& Bielikova, S. O. (2019). Stan ta tendentsii rozvytku turystychnoho kompleksu v konteksti zabezpechennia ekonomichnoi bezpeky Ukrainy [The state and trends of development of 
the tourist complex in the context of ensuring the economic security of Ukraine]. Ekonomika ta derzhava, 9, 17-25. (in Ukrainian)

[17] Więcej turystów zagranicznych w Polsce w 2019 roku [More foreign tourists in Poland in 2019]. E-source: https://www.gov.pl/web/rozwoj-praca-technologia/wiecej-turystow-zagranicznych-w-polsce-w-2019-roku

[18] World bank. E-source: https://www.data.worldbank.org/

[19] International Monetary Fund. URL: www.imf.org

[20] GMR-2020. E-source: https://www.similarweb.com/corp/research/market-research/?utm_source=adwords\&utm_ medium=paid\&utm_campaign=gs_marketresearch_EuropeT23_dsk\&gclid=CjwKCAjw3_KIBhA2EiwAaAAlimcuYIVx Okf8ZFac-ZBfoAbs0GqnM50n2zYO45hEwWk8aJdi8SP1PxoCObcQAvD_BwE 